\title{
A SZŐLÉSZET ÉS BORÁSZAT HELYZETE AZ 1990-ES ÉVEKBEN
}

\author{
(The condition of wine-growing in the 1990s) \\ BODNÁR LÁSZLÓ
}

A szőlő-bor vertikum - a kimutatható fejlődési pálya ellenére is - évtizedek óta a kủlönböző termelési-értékesítési szektorokból származó feszủltségek színtere. Klímaviszonyaink között rendszeresen ismétlődnek az elemi - néha katasztrofális - károk, de ugyanúgy kiugró szőlőtermések is. Termőhelyenként - még nevezetes borvidéken is évjáratok függvényében nagy tehát a mennyiségi, még inkább a minőségi ingadozás. Ennek következtében egyes években borhiány, máskor feldolgozási, tárolásai problémák jelentkeznek. Rendszeresen ismétlödnek a pénzügyi gondok fóként a termelés, a feldolgozás gazdaságossága, máskor a károk felszámolása, de ugyanúgy az új termelókapacitások létesítése, vagy a meglevő korszerúsítése, illetve a készletek finanszírozása területén. A 90-es évekre olyan piaci helyzet alakult ki, hogy az értékesítési lehetőségek jelentỏsen, sőt messze elmaradnak a szölö- és bortermelésünktöl.

A külpiac telítettsége, de a hazai értékesítés nehézségei miatt is létfontosságú a jól végiggondolt, a változó piaci igényekre is tekintő termelés. Ennek feltétele egyfelöl a termelök kapcsolata a feldolgozással, másfelól a teljes vertikum - beleértve a külkereskedelmet is - érdekeltségének a közelítése. Csak így tud a termelés gyorsan és pontosan megfelelni a kívánt színvonalnak és az értékesités is a nagy áldozatokkal megszerzett piaci pozícióknak.

A bel- és külpiaci pozíciók megörzéséhez és kihasználásához sokféle nemzetgazdasági érdek füzödhet. Az általános gazdaság- és agrárpolitikával ősszefüggésben időnként más és más szempontok kaptak hangsúlyt. llyenek pl. a racionális földhasznosítás, vagy a szölötermelés dinamikus növelése, illetve a borászat fejlesztése, máskor térségiborvidéki fejlesztési célok, vagy a nagyüzemi szempontok előtérbe helyezése, megint máskor foglalkoztatási, jövedelemszerzési és -növelési szempontok stb.

A múltra visszatekintve megállapítható, hogy a vertikumra ható tényezők együttes hatásának eredményeként összességében javult az ültetvények szerkezeti összetétele, még inkább termóképessége, de a termelési és borászati kapacitások összhangja is lényegesen jobb ma, mint az 1970-es években volt. Azaz a szólészet és borászat korszerüsége, ezáltal hatékonysága is sokat javult.

A 70-es években indult és a 80-as évek elejéig tartó élénkülő termelési kedvet jelezték a viszonylag kiegyensúlyozott üzemi és az ismét lendületet vett kistermelöi telepítések. Viszonylag egyenletes ütemben emelkedett az átlagtermés mégpedig úgy, hogy közben területcsökkenés ment végbe. Az átlagtermések emelkedése többé-kevésbé kompenzálta a termelési költségek gyors növekedését. A jövedelmezőség azonban - föleg a 
monopol felvásárlási árak hatására - mégis erősen ingadozott. A megvalósított borászati fejlesztések révén azonban végeredményben javult a termelö és a feldolgozó kapacitások összhangja.

A korábbi évtizedek fejlödését kétségkívül az akkori kedvezỏ értékesitési lehetőségek (KGST-piac) motiválták. A viszonylagosan kiegyensúlyozott - lassan csökkenő - hazai borfogyasztás mellett dinamikusan emelkedett a borexport. Tartósan állt fenn olyan piaci helyzet, amelyben az értékesítési lehetőségek - és azok kihasználása - lényegesen meghaladták a bortermelésünket. Az ágazat termelési tervelőirányzatai az értékesítési lehetőségekböl indultak ki, de a termelés korlátaira nemigen tekintettek. Ez sajnos egyoldalúan mennyiségcentrikus szemléletet honositott meg az egész vertikumban. És még így is a borforgalmazás rendre elmaradt az előirányzatoktól, a hazai szőlötermelés „hiányát” olcsó borimport $\mathrm{S}$ az ún. kiegészitö termelés pótolta. Csak ezzel lehetett a VI. ötéves tervidőszak végéig sikerrel teljesítettnek tekinteni a szőlészet-borászat feladatait. Egyidejüleg azonban - sajnos - több vállalatnál fellazult a szakmai igényesség. Alacsonyabb minőségi kategóriájú termékeket - „feljavítva” - magasabb minőségként hozták forgalomba, máskor a feltủntetett termőhely és fajta nem felelt meg a tényleges származásnak és az is előfordult, hogy különféle termékekhez nem természetes (szőlő) eredetü anyagokat használtak fel. Az ebböl és a borimportból származó „előnyök” sajnos szervesen beépültek a borászatra szakosodott szervezetek gazdálkodásába.

Az ellentmondásos "fejlődési” folyamat a 80 -as évek második felében megtört. A sorozatos fagykárosodás átmenetileg 50 ezer ha-on, tartósan pedig 25 ezer ha-on csökkentette az ültetvények termőképességét és szinte egyidejủleg drasztikusan beszükülttek a korábbi ,jó" - mert nem igényes - piacok is. Az utóbbit egyfelől a Szovjetunió importkorlátozása, a KGST viszonylatú árucsere-forgalmi aktívumunk kialakulása, másfelől a hazai fizetőképes fogyasztói kereslet, illetve a termelés mennyisége rövid átmeneti időszakra összhangba került. Ugyanakkor árdiszparitás alakult ki, ami abban jutott kifejezésre, hogy a fagykáros évek viszonylag magas felvásárlási árait a fogyasztói vagy a külkereskedelmi árak már nem viselték el. Növelte a fesziiltséget a közgazdasági szabályozás módosulása (1988. január 1-jétoól), ami a fogyasztói árak növelésére, az adóztatási rendszer megváltoztatására és a hitelezési gyakorlatra egyaránt vonatkozott. Növelte a problémát az is, hogy a belkereskedelem a csökkent forgalom árrés tömegét az árréskulcs növelésével igyekezett kompenzálni. Kétséget kizáróan hozzájárult a vázolt „borpiaci” helyzet romlásához, hogy a fogyasztók bizalma okkal ingott meg a forgalomban levő borok irảnt. Mindez együttesen a forgalom lanyhulásához, túltermelés látszatához, a likviditási és felvásárlási-finanszírozási feszültségek éleződéséhez vezetett.

Más oldalról viszont a mennyiségi szempontok kerültek túlsúlyba és eltorzultak az értékviszonyok. És nemcsak a szőlö- és borárakban mutatkozott meg a bizalomvesztés, de a szakmai fegyelem is fellazult az ágazat az igénytelen - esetenként nyerészkedő piac kiszolgálójává vált. Így aztán napjainkra olyan helyzet alakult ki, amely egyidejüleg hozza felszínre az összes ellentmondást. A felhalmozódottakat és az új keletü feszültségeket együtt.

A szöló-bortermelési ágazat válsághelyzetbe került. Kialakulásában csak másodlagos szerepe volt az ültetvényeket ért súlyos fagykársorozatnak, döntö válságtényezönek azonban az államilag korábban garantált, ezért biztosnak és tartósnak hitt KGST - föleg szovjet - piac beszükülése, majd teljes összeomlás bizonyult. A kialakult helyzetben a borászati üzemek többsége időlegesen átvállalta az általa integrált szólőtermelők tőbbletköltségeit és a készletezés költségeit is. E kényszer miatt jelentős veszteségek leírására kényszerült. 
Kedvezőtlenül hatott az 1983/84-es gazdasági év, amikor 2,6 millió hl bort és pezsgőt exportáltunk a Szovjetunióba. Ennek a mennyiségi tömeg-árutermelésnek a káros következményeit máig sem sikerült megszüntetni. Ezek az évek a „borszerü áruk” korlátlan eladásának időszakai voltak.

$\mathrm{Az}$ ágazat túlzott exportérdekeltsége érvényesült, amikor évente 5 millió körüli volt az átlagtermés, s ennek 60-70\%-át exportálták. A nagyobb hagyományokkal, borkultúrával renđelkező országok mint pl. Franciaország, Olaszország, Spanyolország, Németország az évi termés $60-70 \%$-át belsỏ piacaikon értékesítik, illetve a minőségi áru ,érleléséhez” szükséges tárolókban tartják. Messzebb menve a Dél-Afrikai Köztársaságban az exportképes bor 10\%-át szállítják külföldre.

A hazai viszonyok nem viselték el azokat a korlátozó tényezőket, melyek a minöség és az eredetvédelem rendszerének müködését biztosították volna.

Az 1989-ig érvényben lévő borkereskedelem az állam monopóliuma, $\mathrm{s}$ az ezzel kapcsolatos rendszerszemléletböl hiányzott a tényleges bor-nagykereskedelem. A szölö- és borértékesítésben a külkereskedelmi vállalatok az exportban, belföldön az élelmiszer nagykereskedelmi vállalatok és az ,árnyékgazdaság”-nak nevezett csatornák uralták. A termelő tuzemek borkiméröi is csak választékbövító funkciót töltötttek be.

A Szovjetunió utolsó évében már csak kb. $670000 \mathrm{hl}$ palackos bort és pezsgöt vettek át. Ugyanakkor megszünt a „második” legnagyobb áruátvevő az NDK kb. $450000 \mathrm{hl}$ áru-elhelyezési lehetőséggel. A tradicionálisan tökés exportértékesítési lehetőségünk is tartósan $450000 \mathrm{hl}$ alá esett.

Az egy före eső borfogyasztás a 60-as évek végén prognosztizált 35 liter/föről, 21 liter/före redukálódott hazánkban.

A hagyományosan nagy borfogyasztó országokban is csökkenés következett be a 80as évek második felére. Franciaországban, Olaszországban 10-15 liter/fövel esett vissza a borfogyasztás évente.

Alapvető változás 1991. január 1-jén lépett életbe, amikor a borkereskedelmet liberalizálták. Ettől az időtől már természetes személyek, tehát magántermelök és egyéni vállalkozók is folytathatnak kereskedelmi tevékenységet.

A bor nemzetközi kereskedelmében az utóbbi években ủj piacok is jelentkeztek, '́gy a borfogyasztó államok sorába lépett Anglia, Japán, a skandináv országok stb.

A magyarországi borfogyasztás visszaesése részben a tradíciók nem megfeleló ápolásában, részben a rosszul értelmezett kereskedelmi etika és reklámtilalom együttes kedvezőtlen hatásában keresendő.

Magyarországon a 70-es és 80-as évtizedben elsősorban a mennyiségi szemléleten alapuló termelés- és kereskedelempolitika érvényesült, amely a borászat szerkezeti lemerevedését vonta maga után. Ez egyrészt megmutatkozott a fajtaösszetétel nem kellỏen rugalmas és piacérzékeny kezelésében, másrészt a hagyományok és a nagyüzemi ültetvénykultúra nem szerencsés kezelésében, egy harmonikus rendszer kiépitésének hiányában.

Az exportszerkezet nem megfelelö átrendeződését jelzi, hogy a legjelentősebb tỏkés piacon, Németországban - ahová évente 200-220 $000 \mathrm{hl}$ bort exportálunk, az áru több mint $50 \%$-át még mindig a hordós bor adja. Ez lényegében alapanyag szállítói pozíciót jelent, melyböl a német nagykereskedők húznak hasznot.

Az 1990. évi exportadatok jól tükrözik az importált és exportált mennyiséget, a borés bortermékek struktúráját.

Jelentős változás a borexportban 1991-ben következett be, amikor az Egyesült Királyságban vásárlás-növekedés következett be, míg a egyesített Németországban a pa- 
lackozott borok vásárlásának aránya ugyan növekedett, azonban nem közelítette meg a korábbi exportált mennyiséget.

A borimport 1986-ban érte el a csúcspontját a súlyos fagykárok miatt. Jelentősebb importra került sor 1995-ben is, amikor a peronoszpóra, s ezzel összefüggésben a rossz minőségủ nỏvényvédő szerek importja idézett elő nagy terméskiesést.

199l-ben az import alig haladta meg a 100 ezer hl, amely leginkább a barter (árucsere) szerződéseken alapult. Az importnak csak kis része érkezett globálkvóta keretén belül hazánkba.

A külpiaci tendenciák egyértelmüvé teszik, hogy a régebbi, számunkra kedvezö exportarány nem fog visszatérni. Ez pedig a hazai fogyasztásra irányítja a figyelmet, felértékelve az eddigiekhez képest a magyar fogyasztót. Érdekessé válik, hogy milyen bort keresnek a hazai fogyasztók, mennyi pénzt tudnak érte adni. Az eredetvédelem, a minöség megbecsülése helyett a kommersz típusú borok uralják a piacot. Az is megfigyelhető, hogy a magyar fogyasztók reagáltak az exportból visszamaradt tömegáruk elterjedésére, 20-30 év alatt felére csökkent az egy före jutó borfogyasztás. A motorizáció elterjedésével vagy a növekvő uidítőital fogyasztással magyarázzák többen ezt a csökkenést. Valójában ez nem igazi ok. A fordulópont a hazai piacon is 1991-ben következett be, amikor is a folyamatos csökkenés és stagnálás helyett jelentős növekedés következett be a borfogyasztásban. Ennek fó oka az olcsó kannás borok elterjedése volt. Olyan helyzet alakult ki, hogy egy liter olcsó bor ára ugyanannyi lett, mint egy fél liter átlagos minöségü söré.

A „tizes” élbolyban 1995-ben Magyarországon már 34,7 literre emelkedett az egy före jutó fogyasztás, ahol a nyolcadik helyet foglaltuk el. Megelózött bennünket Franciaország (63,5 liter), Olaszország (60,4 I), Portugália (58,4 I), Luxemburg (58,2 I), Argentína $(43,8$ I), Svájc $(43,6$ l) és Spanyolország $(36,3$ l). Utánunk következik Görögország (34,5 I), Ausztria (32 I).

A társadalom jelentős mértékủ polarizálódása a keresletet polarizálódását is magával vonta. Egyes rétegeknél mind nehezebb a megélhetés, ők a minél olcsóbb bort keresik. A hirtelen meggazdagodottak a legdrágább borokat a legelökelöbbnek vélt helyeken vásárolják meg. Tehát a legolcsóbb és a legdrágább borok iránt van a legnagyobb kereslet.

A külföldi statisztikák szerint a minöségi borok fogyasztói leginkább a középosztály tagjai közül kerülnek ki. Hazánkban ez a réteg sajnos még nem erösödött meg kellö mértékben és nem engedheti meg magának azt, hogy az étkezésekhez egy-két pohár jó bort megigyon. Még inkább nincs lehetösége arra, hogy rendszeresen vendéglökben étkezhessen. A magyar borok csupán 1\%-a értékesül a vendéglátóiparban és ha a borozókat és a talponállókat is figyelembe vesszük, ez akkor sem több 5\%-nál.

A borfogyasztás klasszikus színterei a különbözö vendéglátóipari egységek. Magyarországon ezek közel sem töltik be azt a funkciót, amely a borkultúra növelésében, a borfogyasztás mennyiségének és színvonalának emelésében rájuk hárulna. Jelentős hiányossága a vendéglátóipari borértékesitésnek, hogy kevés és laza kapcsolat van a borászati vállalatok és vendéglátóipari egységek között. Így könnyen elöfordulhat, hogy egyegy vendéglőben az adott tájegységre jellemzö borokat nem lehet megvásárolni.

Az 1991-1995 közötti idöszakban is tovább folytatódtak a nem kívánt irányzatok, tovább csőkkent az összes szölőterület, ezen belül is a termóterület (1.ábra, l. táblázat). Bár a termésátlag kis mértékben nött, de a termésmennyiség a termöterület csökkenésével párhuzamosan csökkent. A bortermelés jelentős visszaesést mutat. Az 1986-1990 évek átlagához viszonyítva, amikor is 4 millió 310 ezer hl volt, 199l-1995 évek átlagában 3 millió 820 ezer hl volt. 
Bodnár László : A szőlészet és borászat helyzete az 1990-es években

Tér és Társadalom 10. évf. 1996/4. 153-163. p.

\section{1. ÁBRA}

A szölötermelés alakulása 1985 és 1995 között

(The development of viticulture in 1985-1995)
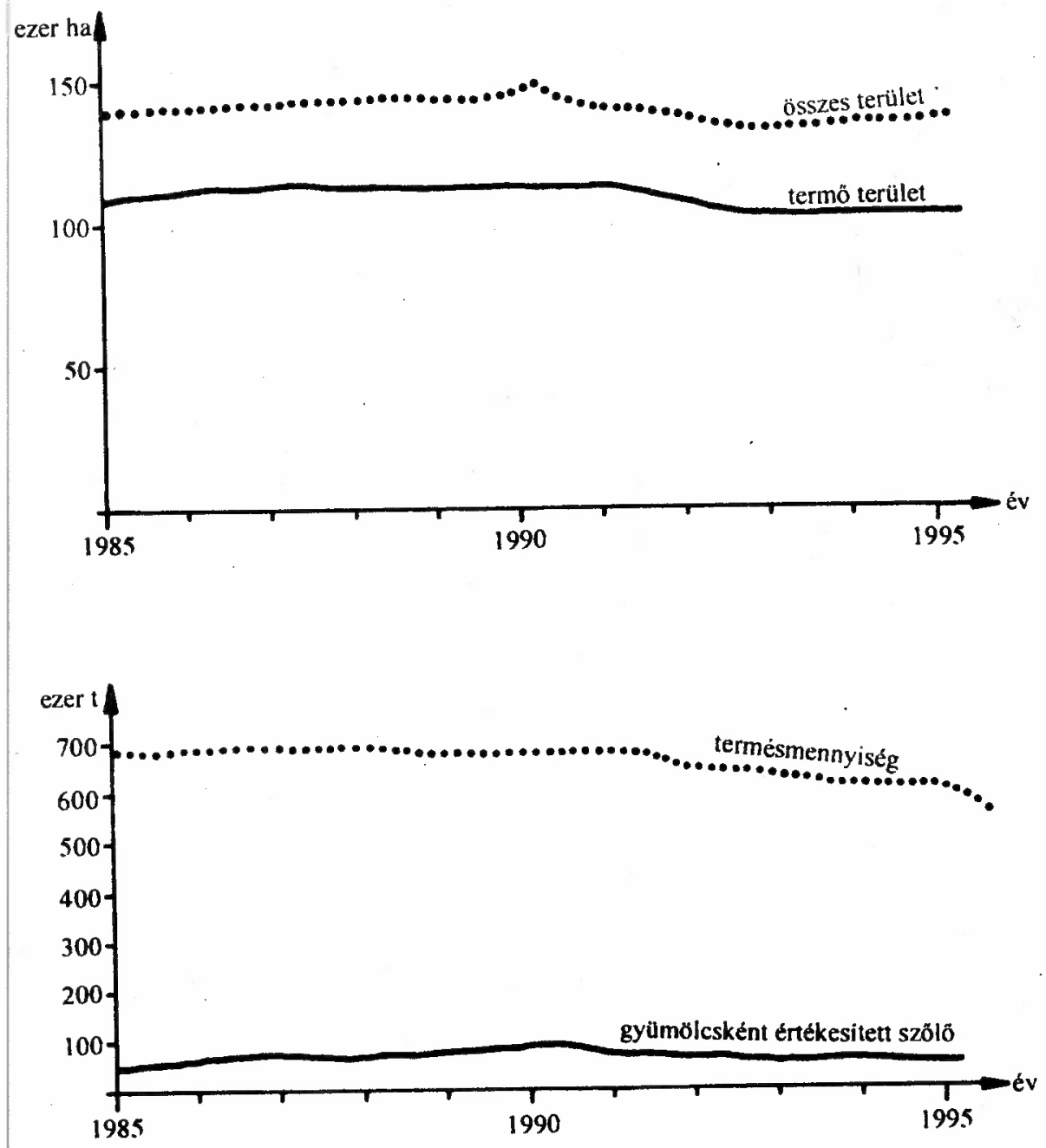

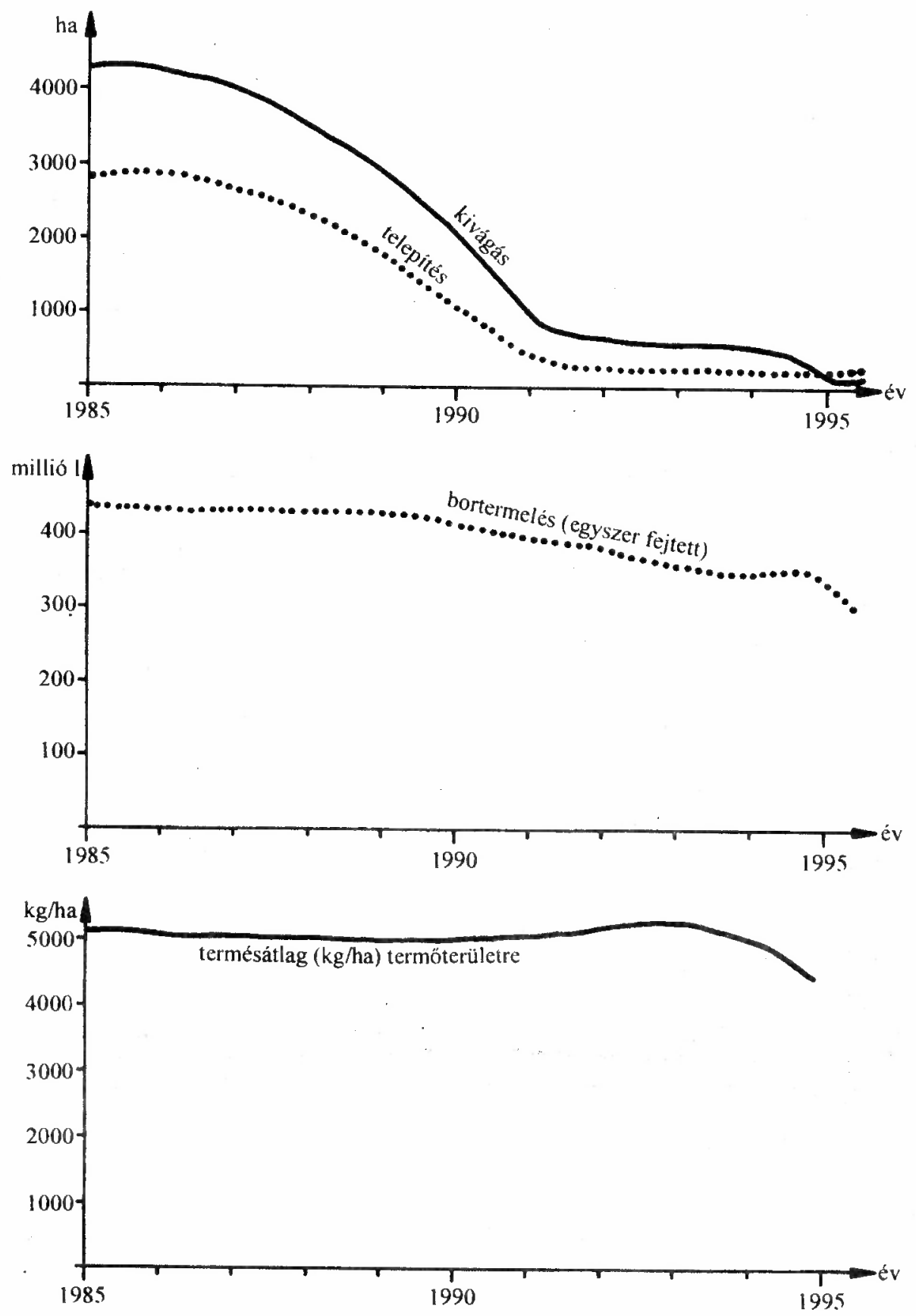
Tér és Társadalom 10. évf. 1996/4. 153-163. p.

\begin{tabular}{|c|c|c|c|c|}
\hline \multicolumn{5}{|c|}{$\begin{array}{l}\text { 1. TÁBLÁZAT } \\
\text { A szôlö-és bortermelés alakulása a számok tükrében } \\
\text { (Grape-and wine production as reflected by figures) }\end{array}$} \\
\hline Megnevezés & $\begin{array}{l}\text { 1986-1990. } \\
\text { evek átlaga }\end{array}$ & $\begin{array}{l}\text { 1991-1995. } \\
\text { évek átlaga }\end{array}$ & 1994 & 1995 \\
\hline Összes terulet, ezer ha & 143 & 133 & 132 & 131 \\
\hline Termöterullet, ezer ha & 112 & 106 & 101 & 100 \\
\hline Termésátlag, kg/ha (termöterületre) & 5100 & 5210 & 5003 & 4810 \\
\hline Termésmennyiség, ezer $\mathrm{t}$ & 676 & 637 & 614 & 544 \\
\hline Gyümölcsként értékesített szőlö, ezer t & 45 & 48 & 42 & 36 \\
\hline Bortermelés (egyszer fejtett), millió I & 431 & 382 & 369 & 329 \\
\hline Telepítés, ha & 2702 & 173 & 72 & 56 \\
\hline Kivágás, ha & 4030 & 851 & 404 & 49 \\
\hline
\end{tabular}

Az 1991-1995 évek átlagában megyénkénti összehasonlításban a Dunántúlon a legnagyobb szölöterülettel Veszprém, Zala, Tolna, Somogy és Baranya rendelkezett. Kisebb területe volt Fejér, Györ-Moson-Sopron, Vas megyének.

Az Alföldön Bács-Kiskun, Pest, Csongrád megye után Hajdú-Bihar, SzabolcsSzatmár-Bereg, Jász-Nagykun-Szolnok, Békés megye következik. ÉszakMagyarországon Borsod-Abaúj-Zemplén és Heves megye után Nógrád megyében jelentéktelen a szőlöterület aránya.

Az 1991-1995 évek átlagában az összterületen belül a szőlöterület aránya 79,48\%, amelyen belül a Dunántúlon $86,28 \%$, az Alföldön 73,9\%, Észak-Magyarországon $80,69 \%$. Az országos átlagot jóval meghaladja Heves megye, ahol $87,78 \%$ a termőterület aránya. Ez egyben jelzi azt, hogy a két történelmi borvidéken - a Mátraalján és az egri borvidéken - még most is kiemelt szerepet tulajdonítanak a szőlö- és borkultúrának (2. ábra).

A termőterület termésátlaga országosan $5207 \mathrm{~kg} / \mathrm{ha}$ volt az 1991-1995. évek át'agában. Kiugróan magas értéket mutat Heves megye $8025 \mathrm{~kg} / \mathrm{ha}$, majd Somogy és Tolna következik. Igen alacsony az Alföldön, igy Csongrád, Békés, Szabolcs-Szatmár-Bereg, Hajdú-Bihar, Jász-Nagykun-Szolnok megyében (2. táblázat).

Az utóbbi években más gondok is jelentkeztek. A szüret után a szövetkezetek, de ugyanúgy az egyéni gazdák sem kapták meg idejében a szőlöért járó pénzt. Ezáltal arra sincs anyagi biztositék, hogy a tavaszi munkálatok idejében és megfelelö minöségben elkészüljenek. Romlik a termelési kedv, csökken a telepítések nagysága, uralkodóvá válik a szőlő kivágása. A növényvédelmi teendők elmaradása is ronthatja vagy tönkreteheti a történelmi borvidék állapotát. Szőlőtelepitésről pedig már nem is igen beszélnek, mert annak költsége meghaladja az egymillió forintot hektáronként.

Az egri hegyközség területén már 1996 őszén vita alakult ki a kékszőlőfajták mustjának exportjáról. A szüret időszakában a must egy részét Csehországba, Lengyelországba, Szlovákiába, Szlovéniába szállították. Ez károkat okozhat, mert pl. az egri Bikavér alapanyagát szállítják ki és idehaza nem készült belóle bor. Ez az akció a piacok elvesztését is jelentheti. A hegyközségeknek viszont nincs jogi eszköze arra, hogy ezt megakadályozza. Ezért meg kell találni azt az összhangot, amely a minőségnek megfelelöen fogalmazza meg a felvásárlási árakat. Csakis igy érhetô el a garantált minőség a világpiacon. Természetesen más gondok is jelentkeztek. Akadt olyan felvásárló az egri borvi 


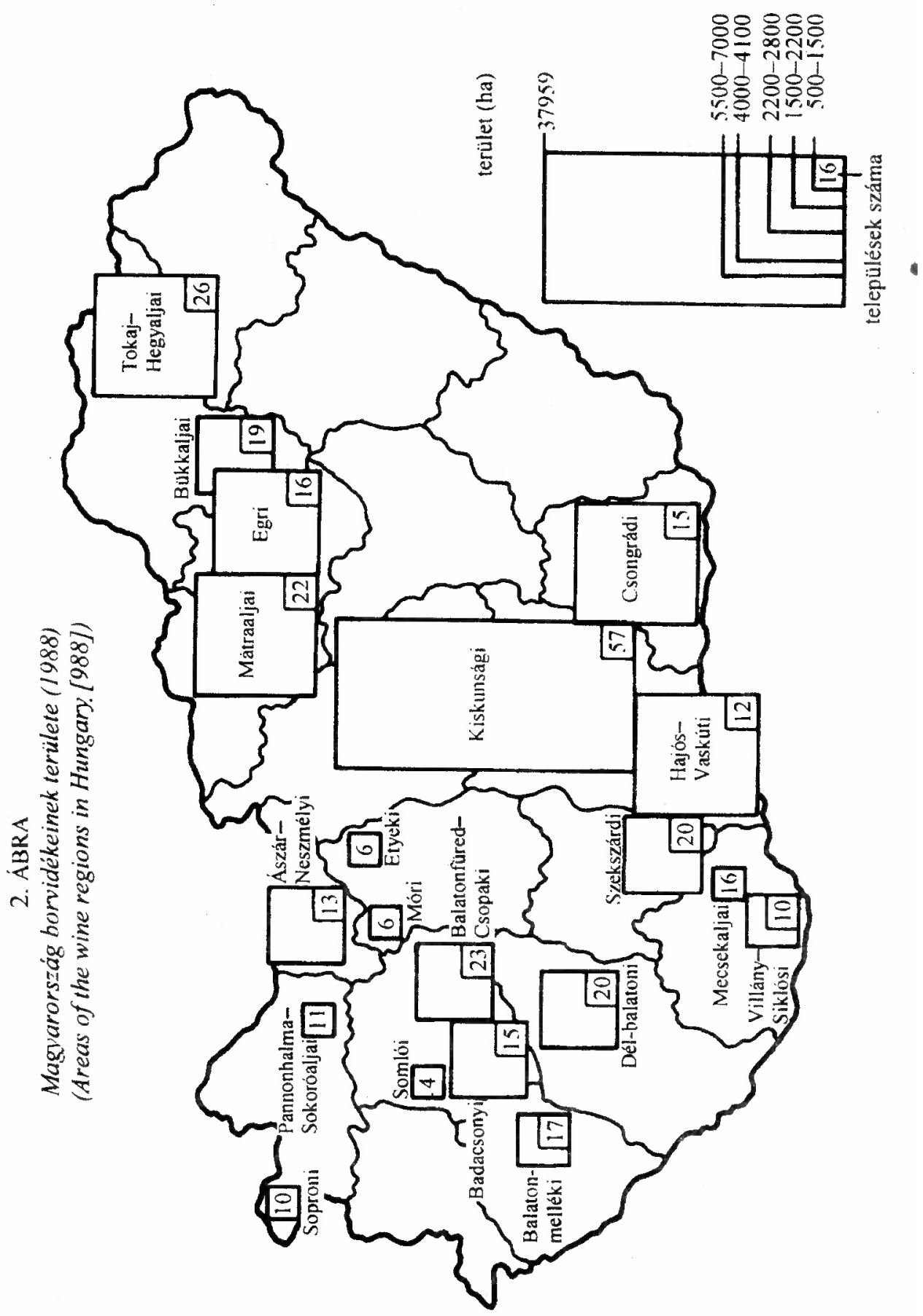


Bodnár László : A szőlészet és borászat helyzete az 1990-es években

Tér és Társadalom 10. évf. 1996/4. 153-163. p.

\section{TÁBLÁZAT}

A szólőtermelés helyzete 1991-1995. évek átlagában megyénként

(The situation of viticulture in 1991-1995, by counties)

\begin{tabular}{|l|r|r|r|r|r|}
\hline \multicolumn{1}{|c|}{ Megye } & $\begin{array}{c}\text { Szölöterület } \\
\text { (ha) }\end{array}$ & $\begin{array}{c}\text { Ebböl termö- } \\
\text { területek }\end{array}$ & $\begin{array}{c}\text { Összes ter- } \\
\text { mésmennyiség } \\
\text { (tonna) }\end{array}$ & $\begin{array}{c}\text { Ebböl termö- } \\
\text { területen } \\
\text { termett (tonna) }\end{array}$ & $\begin{array}{c}\text { Termöterület } \\
\text { termésátlaga } \\
\text { (kg/ha) }\end{array}$ \\
\hline Baranya & 4989 & 4101 & 24200 & 21498 & 5242 \\
Fejér & 3766 & 3603 & 18758 & 16471 & 4571 \\
Györ-Moson-Sopron & 3559 & 3430 & 23482 & 18876 & 5503 \\
Komárom-Esztergom & 3779 & 3275 & 19743 & 18056 & 5514 \\
Somogy & 6081 & 5357 & 39418 & 37271 & 6957 \\
Tolna & 6354 & 5406 & 36026 & 33653 & 6225 \\
Vas & 1594 & 1565 & 8537 & 7049 & 4504 \\
Veszprém & 8190 & 6852 & 42836 & 36807 & 5369 \\
Zala & 7017 & 5524 & 28306 & 25468 & 4610 \\
\hline D u n án t ú I & 45329 & 39113 & 241306 & 215149 & 5007 \\
\hline Bács-Kiskun & 37767 & 25842 & 150569 & 121465 & 4700 \\
Békés & 236 & 231 & 2819 & 747 & 3234 \\
Csongrád & 5419 & 5050 & 16973 & 15431 & 3055 \\
Hajdú-Bihar & 2755 & 2180 & 7921 & 7760 & 3560 \\
\hline Jász-Nagykun-Szolnok & 2501 & 2410 & 12355 & 9466 & 3928 \\
Pest & 9269 & 6909 & 37767 & 31129 & 4510 \\
Szabolcs-Szatmár-Bereg & 2790 & 2264 & 7780 & 7526 & 3324 \\
\hline A l f o ld & 60737 & 44886 & 236184 & 193524 & 4311 \\
\hline Borsod-Abaúj-Zemplén & 12951 & 9802 & 54409 & 49381 & 5038 \\
Heves & 11690 & 10262 & 91055 & 82357 & 8025 \\
Nógrád & 1115 & 721 & 3844 & 3205 & 4445 \\
É s z a k & 25756 & 20785 & 149308 & 134943 & 6492 \\
\hline VIDÉK ÖSSZESEN & 131822 & 104784 & 626798 & 543616 & 5187 \\
\hline Budapest & 1478 & 1257 & 10581 & 8856 & 7645 \\
\hline ORSZÁG ÖSSZESEN & 133300 & 106041 & 637379 & 552472 & 5209 \\
\hline
\end{tabular}

déken aki már a szólő biológiai érése előtt kezdte meg az átvételt. Ezzel még súlyosabb károkat okozott, mint akik a must külföldi értékesítésére szánták el magukat. Az így készített must minősége is erősen megkérdőjelezhetö.

Az elmondottakból következik, hogy elöször is egy stratégia kialakítására van szükség. Vagyis a szőlöből, borászatból élök rétegének megfelelỏ perspektívát kell látnia maga elött a szőlészetben és a borászatban. Ebben kölcsönösen segíthetnek az érdekelt települések önkormányzatai, a szölö- és bortermelök egyesületének helyi tagjai, valamint a szövetkezetek. Ha így életképes tulajdoni hányad, tulajdonosi szervezet jönne létre, akkor kezdeményezően léphetnének fel a korábbi hitelezỏkkel, a bankokkal szemben. Úgy például, hogy követeléseiket tulajdonosi részre váltsák át. Vagyis, hogy a történelmi borvidék iránt lojális tulajdonosként lépjenek be egy majdani társaságba.

$\mathrm{Az}$ eredetvédelem intézményi háttere a hegyközségi törvény életbelépésével, a hegyközségek újraszerveződésével vált ismét lehetővé. Ez a rendszer a termelök önszabályozó és önellenőrző szervezete, amely az állami szabályozást és ellenőrzést is kiegészíti. 
A fogyasztás jelenlegi helyzete, a gazdasági környezet és annak várható alakulása indokolttá teszi egy olyan marketing stratégia kialakitását, amely képes választ adni a kihívásokra.

A magyar szőlö- és bortermelők számára az eredetvédelem fejlesztése nemcsak a Közös Piac által igényelt tevékenység, hanem gazdasági kényszer is. A termelés csökkenéséből adódó veszteségek részleges vagy jelentős pótlása csak akkor képzethető el, ha a védett eredetũ borok egy nagyobb hazai és exportpiaci részesedést érnek el, ott termelői, szabályozási garanciảjuk következtében jelentős árbevételt jelenthetnek. A termelőknek és a kereskedőknek meg kell találni a származási hely megnevezése és a márkák közöttti harmóniát is. Az eredetvédelem a borászati feldolgozást, a borvidékeket, a hazai és exportpiacot, valamint a fogyasztást is erőteljesen differenciálja.

Meggyőződésem, hogy a szőlö- és borágazat jelenlegi súlyos helyzetéből is képes a megújulásra, a hatékony piaccentrikus termelés megvalósítására. Erre a megújhodásra annál is inkább szükség van, mert területi elhelyezése mindig is nagyszámú munkahelyet, gazdasági felvirágzást biztosított, illetve hozott, különösen a történelmi borvidékeknek. Más termelési kultúrával a szőlészet itt nem is helyettesíthető. A borgazdaságok feldolgozó kapacitása is nagy érték és más célra nem is igen konvertálható. A szőlészet és borászat volt itt a legfontosabb agrárágazat, a nagyủzemek, az egyéni termelök pénzeszközeiket ebbe a „legeredményesebb” ágazatukba, a bortermelésbe fektették, amihez még jelentős hiteleket is igénybe vettek.

Megjegyzendő, hogy a világ ismert „zárt” borvidékein kb. 35-45 millió hektoliter bor terem. Ezek a minőségi borok folyamatosan növekvő áron találnak vevőre a világpiacon. A szigorúan szabályzott termelés is elősegíti a piaci egyensúlyt. Ebbe a minőségi piaci körbe kell a magyar történelmi borvidékeket bejuttatni, s a még el nem feledett eredetés minőségvédelmével, hatékony piacszervező (marketing) tevékenységgel a magyar bor hírnevét ott megörizni.

Irodalom

Bodnár L. (1987) Az egri és a mátraaljai tơrténelmi borvidék. Heves Megyei Tanács Mg. Osztálya, Eger.

Bodnár L. (1990) A szölö és borértékesítés gondjai Heves megye történelmi borvidékein. In: Tér-idốtársadalom. MTA Regionális Kutatások Központja, Pées, 418-430. o.

Bodnár L. (1991) A szỏlö és bortermelés gondjai, különös tekintettel az egri ès a mátraaljai tơrténelmi borvidékre. Acta Academiae Paedagogicae Agriensis Nova Series Tom. XX. 21-36. o.

Bodnár L. (1994) A szölészet és borászat helyzete az 1990-es években. Acta Academiae Paedagogicae Agriensis Nova Series Tom. XXI. 5-20. o.

Nemzetkőzi Statisztikai Zsebkönyv. KSH, Budapest, 1987

A gyưmőlcs-és szőlötermelés 1990. évi föbb eredményei. KSH Mg. Statisztikai Főosztály, Budapest.

A borkereskedelem ABÉCÉJE. Pelsovin Trade BT. Balatonfüred, 1993.

Magyar Statisztikai Zsebkonnyv. KSH, Budapest, 1995. 


\title{
THE CONDITION OF WINE-GROWING IN THE 1990S
}

\author{
LÁSZLÓ BODNÁR
}

Nowadays we can witness a rearrangement process in the field of wine-growing and wine-producing. One of the reasons is the significant slackening of market possibilities, and also the growing quality requirements. The mistakes, unclassified questions of profit-process become more and more acute. Exportation-centredress of wine-producing should remain, it is of great importance. It can be realized through a more standardized requirement-system in the field of both foreign and home Trade ensure this we need a fixed production basis, carefully elaborated concepts concerning our activity in the foreign market. Sooner our exportation was characterized by a one-channel sale-system. Nowadays, however, wine is delivered to the foreign market by more trade and exporting companies. The development of wine-growing and wine-producing, which could meet the necessary demands, is possible in perspective only. The present situation, on the one hand, defines the next measures, but in the perspective, on the other hand, it also limitations the size and pace of the development.

To restore the harmony between production and consumption, to make distorted price and value relations meet market value standards, to privide a profitable production on ground of utilizing oecological, biological and technological reserves, to validate the points of view of origin, naming and quality-loyalty in the product-structure are urgent tasks in the field of wine-producing. We need differentiated consumer prices in the country which would be in harmony with consumption prices and solvent demands. The exportation orientated character of wine-producing requires grounded foreign trade activity. 